\title{
KESESUAIAN MEKANISME PEMBIAYAAN MURABAHAH PRODUK KPR MENURUT FATWA DSN MUI DI BANK JATIM SYARIAH SURABAYA CABANG DARMO 1)
}

\author{
Dara Setianti Kania P \\ Program Studi S1 Ekonomi Islam-Fakultas Ekonomi dan Bisnis Universitas Airlangga \\ Email : darasetiantikania@yahoo.co.id \\ Siti Inayatul Faizah \\ Departemen Ekonomi Syariah-Fakultas Ekonomi dan Bisnis Universitas Airlangga \\ Email : inay.hakim@gmail.com
}

\begin{abstract}
:
This research aims to determine how the suitability of handling Murabaha financing problem house loan product at fatwa of the National Sharia Supervisory Board of the Indonesian Ulama Council (DSN-MUI) in Bank Jatim Sharia Surabaya. The object of the study are Bank Jatim Sharia's competent employees which competent in murabaha financing. This study used qualitative descriptive approach. The researcher collected the data by interviewing three employees of Bank Jatim Sharia.This research finds that the six points which used as references in the study such as price, advance, fine, guarantee, and collectability murabaha financing of House Loan product are suitable with fatwa of the National Sharia Supervisory Board of the Indonesian Ulama Council (DSN-MUI). But, there is one which doesn't suitable with fatwa.
\end{abstract}

Keywords: Akad Murabaha, Sharia House Loan, Fatwa DSN-MUI, Bank Jatim Sharia.

\section{PENDAHULUAN}

Seiring dengan perkembangan zaman pada era modernisasi saat ini kebutuhan masyarakat akan vang semakin berkembang pesat. Masyarakat membutuhkan lembaga keuangan yang berfungsi sebagai tempat untuk melakukan investasi, atau sebagai tempat untuk menyimpan dana. Kemudian muncul lembaga keuangan yang dikenal masyarakat sebagai bank. Kata bank berasal dari banque dalam bahasa Perancis, dan dari banco dalam bahasa Italia, yang berarti peti/lemari atau bangku menyiratkan fungsi sebagai tempat menyimpan benda-benda berharga (Sudarsono, 2008:27).
Perbankan konvensional terdapat kegiatan-kegiatan yang dilarang Syariah Islam, seperti menerima dan membayar bunga (riba), membiayai kegiatan produksi dan perdagangan barangbarang yang dilarang syariah. Bank Syariah didirikan dengan tujuan untuk mempromosikan dan mengembangkan penerapan prinsip-prinsip Syariah Islam dan tradisinya ke dalam transaksi keuangan dan perbankan serta bisnis lain yang terkait.

Perbankan syariah di Indonesia telah menjadi tolak ukur keberhasilan eksistensi ekonomi syariah. Bank Muamalat sebagai bank syariah pertama dan menjadi pioneer bagi bank syariah lainnya

1) Jurnal ini merupakan bagian dari skripsi dari Dara Setianti K.P, NIM : 041114108 , yang diuji pada 29 Januari 2016 
Kania, et al/Jurnal Ekonomi Syariah Teori dan Terapan Vol. 3 No. 3 Maret 2016: 235-248; KESESUAIAN MEKANISME PEMBIAYAAN MURABAHAH PRODUK KPR MENURUT FATWA DSN MUI DI BANK JATIM SYARIAH SURABAYA CABANG DARMO

telah lebih dahulu menerapkan sistem ini di tengah menjamurnya bank-bank konvensional. Krisis moneter yang terjadi pada tahun 1998 telah menenggelamkan bank-bank konvensional dan di likuidasi karena kegagalan sistem bunganya. Sementara perbankan yang menerapkan sistem syariah dapat tetap eksis dan mampu bertahan.

Bank syariah memiliki ketentuan yang berbeda dengan bank konvensional dalam memenuhi modal serta penyaluran pembiayaan. Dapat dilihat produk-produk bank terdiri atas tiga kategori, yaitu : produk penyaluran dana (financing), produk penghimpunan dana (funding) dan produk jasa (services).

Keberadaan bank syariah di Jawa Timur sudah semakin banyak, khususnya di Surabaya. Salah satunya adalah Bank Jatim Syariah. Sebagai lembaga keuangan yang terpercaya Bank Jatim Syariah membangun karakter Sumber Daya Insani (SDI) dengan prinsip luhur yang dicontohkan oleh Rasulullah SAW yaitu insan BJS yang beriman, cerdas, amanah, jujur, berkomunikasi dengan baik.

\section{Pembiayaan}

Murabahah merupakan pembiayaan yang lebih dominan dibandingkan pembiayaan lain yang ditawarkan oleh bank syariah. Murabahah merupakan akad jual beli yang menggunakan sistem margin, pihak bank membeli barang yang di inginkan oleh nasabah kepada penjual, lalu nasabah membeli barang dari bank dengan keuntungan (marjin) yang diberikan kepada bank sebagai imbalan jasa bank memberi pembiayaan kepada nasabah. Pembiayaan murabahah memberikan jaminan atas kesepakatan akad yang telah dilakukan oleh kedua belah pihak, jaminan yang diberikan bertujuan untuk menghindari adanya pembayaran macet yang dilakukan oleh nasabah. Jika nasabah pembiayaan murabahah mengalami pailit atau bangkrut dalam pembayaran maka bank syariah wajib memberi kelonggaran pembiayaan sampai nasabah yang berhutang dapat membayar hutangnya kembali

Seperti dijelaskan dalam Q.S. alBaqarah ayat 280 berikut ini

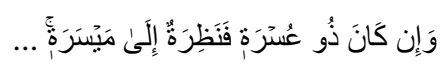

Wa in kana zu 'usratin fanaziratun ila maisarah(tin)

Artinya : "Dan jika (orang berhutang itu) dalam kesukaran, berilah tangguh sampai dia berkelapangan..." (Q.S. al-Baqarah (2):280)

Penjelasan dari ayat di atas adalah jika seseorang memiliki hutang kemudian mengalami kebangkrutan atau benar-benar tidak dapat membayar hutang maka berilah kelonggaran sampai dapat membayar kembali hutang tersebut. Sesungguhnya menolong orang yang kesusahan maka akan dipermudah jalannya didunia maupun akhirat.

Produk pembiayaan Bank Jatim Syariah tidak berbeda dengan bank-bank syariah lainnya. Bank Jatim Syariah memberikan pembiayaan yang meliputi 
Kania, et al/Jurnal Ekonomi Syariah Teori dan Terapan Vol. 3 No. 3 Maret 2016: 235-248; KESESUAIAN MEKANISME PEMBIAYAAN MURABAHAH PRODUK KPR MENURUT FATWA DSN MUI DI BANK JATIM SYARIAH SURABAYA CABANG DARMO

pembiayaan investasi atau produksi, pembiayaan modal kerja dan pembiayaan konsumtif. Terdapat beberapa akad yang digunakan dalam pembiayaan Bank Jatim Syariah, salah satunya yaitu akad murabahah. Pembiayaan murabahah yang banyak diminati nasabah diterapkan dalam bentuk Kredit Pemilikan Rumah. Kredit Kepemilikan Rumah (KPR) adalah sebuah pembiayaan konsumtif yang digunakan sebagai cara untuk memiliki rumah, produk pembiayaan ini memberi kemudahan untuk masyarakat yang menginginkan tempat tinggal yang layak dan pembayarannya dapat dilakukan dengan angsuran.

Kehati-hatian diperlukan bagi bank syariah mengingat resiko dalam pembiayaan murabahah rentan terjadi. Proses realisasi pembiayaan di Bank Syariah tidak semulus dan semudah yang dibayangkan. Karena tidak semua nasabah memiliki karakter bisnis yang sama satu dengan yang lain. Ketidaklancaran angsuran pembiayaan oleh nasabah menyebabkan adanya kolektabilitas pembiayaan/penggolongan status pembiayaan. Kolektabilitas merupakan kemampuan pembayaran pokok atau angsuran pokok dan margin pembiayaan oleh nasaba. Berdasarkan ketentuan Bank Indonesia kolektabilitas dari suatu pinjaman dapat dikelompokkan yaitu lancar, dalam perhatian khusus, kurang lancar, diragukan, macet. Kolektabilitas yang buruk akan mempengaruhi Non Performing Finance (NPF) pada bank itu sendiri, maka bank akan melakukan upaya untuk meminimalkan resiko pembiayaan.

Untuk meminimalisir resiko yang terjadi, masalah pengawasan merupakan bagian paling penting. Pengawasan bank syariah lebih ditekankan dalam mengurangi resiko dalam pelaksanaan pembayaran angsuran. Oleh karena itu, diperlukan pengawasan dari pihak bank syariah kepada nasabah yang akan diberikan pembiayaan, khususnya pembiayaan murabahah yang sering diterapkan di bank syariah.

Dalam kegiatan operasionalnya khususnya terkait produk dan pengawasan, bank syariah berpedoman pada fatwa yang dikeluarkan Dewan Syariah Nasional Majelis Ulama Indonesia (DSN MUI). DSN MUI merupakan langkah efisiensi dan koordinasi para ulama dalam menanggapi isu-isu yang berhubungan dengan masalah ekonomi dan keuangan. Keberadaan bank syariah di Indonesia masih baru berkembang sehingga terindikasi masih ada tindakan dari pihak bank yang tidak sesuai dengan fatwa DSN-MUI.

Berdasarkan uraian di atas, penulis tertarik untuk meneliti bagaimana pengawasan dan penanganan pembiayaan murabahah produk KPR. Sehingga penulis mengambil judul "Kesesuaian Fatwa DSN-MUI Dalam Penanganan Pembiayaan Murabahah Bermasalah Produk Kepemilikan Rumah di 
Kania, et al/Jurnal Ekonomi Syariah Teori dan Terapan Vol. 3 No. 3 Maret 2016: 235-248; KESESUAIAN MEKANISME PEMBIAYAAN MURABAHAH PRODUK KPR MENURUT FATWA DSN MUI DI BANK JATIM SYARIAH SURABAYA CABANG DARMO

\section{Bank Jatim Syariah Surabaya Cabang Darmo"}

\section{LANDASAN PUSTAKA}

Muhammad (2000:47) dalam bukunya menjelaskan bahwa UndangUndang Perbankan Syariah No.21 Tahun 2008 menyatakan perbankan syariah adalah segala sesuatu yang menyangkut tentang bank syariah dan unit usaha syariah, mencakup kelembagaan, kegiatan usaha, serta cara dan proses dalam melaksanakan kegiatan usahanya. Bank syariah adalah bank yang menjalankan kegiatan usaahanya berdasarkan prinsip syariah (BUS), unit usaha syariah (UUS) dan bank pembiayaan rakyat syariah (BPRS).

Bank syariah adalah bank yang beroperasi dengan tidak menggunakan sistem bunga. Bank syariah adalah lembaga keuangan atau perbankan yang operasional atau produknya dikembangkan berdasarkan pada AlQuran dan hadits. Dengan kata lain bank Islam adalah lembaga keuangan yang usaha pokoknya memberikan pembiayaan dan jasa-jasa lainnya dalam lalu lintas pembayaran serta peredaran vang yang pengoperasiannya disesuaikan dengan prinsip syariat Islam. (Muhammad, 2000:13).

Bank syariah merupakan bank yang secara operasional berbeda dengan bank konvensional. Prinsip utama operasional bank syariah adalah sesuai AlQuran dan hadits sebagai pedoman. Bank syariah tidak boleh menjalankan transaksi yang dilarang Al-Quran dan hadits seperti mengandung unsur bunga (riba), judi (maysir), serta hal-hal yang tidak jelas (gharar).

Murabahah berasal dari kata "Ribh" yang berarti keuntungan laba atau tambahan (Ascarya, 2011:19). Menurut Fatwa Dewan Syariah Nasional-Majelis Ulama Indonesia (DSN-MUI) Nomor 04/DSNMUI/IV/2000 tentang murabahah. Pembiayaan murabahah adalah akad pembiayaan suatu barang dengan menegaskan harga belinya kepada pembeli dan pembeli membayarnya dengan harga yang lebih sebagai keuntungan yang disepakati. Menurut (Karim, 2007: 113) murabahah adalah akad jual beli barang dengan menyatakan harga perolehan dan keuntungan (margin) yang disepakati oleh penjual dan pembeli. Kedua belah pihak harus menyepakati harga jual dan jangka waktu pembayaran. Harga jual dicantumkan dalam akad jual beli dan jika telah disepakati tidak dapat berubah selama berlakunya akad. Pembiayaan murabahah selalu dilakukan dengan cara pembayaran cicilan. Dalam transaksi ini barang diserahkan segera setelah akad, sedangkan pembayaran dilakukan secara tangguh/cicilan.

Berdasarkan pengertian di atas dapat disimpulkan bahwa penggunaan akad murabahah lebih mudah perhitungannya karena harga sudah ditetapkan di awal. Akad murabahah ini biasa diterapkan dalam pembiayaan 
Kania, et al/Jurnal Ekonomi Syariah Teori dan Terapan Vol. 3 No. 3 Maret 2016: 235-248; KESESUAIAN MEKANISME PEMBIAYAAN MURABAHAH PRODUK KPR MENURUT FATWA DSN MUI DI BANK JATIM SYARIAH SURABAYA CABANG DARMO

untuk pengadaan alat investasi serta kebutuhan konsumtif masyarakat. Murabahah sangat berguna bagi seseorang yang membutuhkan dana untuk kebutuhan yang mendesak sedangkan pembayarannya dapat dilakukan dengan cara angsuran. Pembiayaan ini juga biasa dimanfaatkan oleh sektor usaha yang memiliki keterbatasan modal untuk memenuhi kebutuhan alat-alat produksinya, sehingga membutuhkan lembaga keuangan yang mampu menyalurkan pembiayaan dengan menggunakan akad jual beli tangguh.

Untuk menggambarkan alur transaksi murabahah secara umum dapat dilihat pembiayaan murabahah dapat dijelaskan pertama bank dan nasabah melakukan negosiasi atau kesepakatan untuk transaksi akad, diantaranya yaitu harga, berapa keuntungan yang di terima oleh pihak bank, serta kesepakatan uang muka yang diberikan diawal perjanjian. Kedua, terjadi kesepakatan akad jual-beli antara pihak bank syariah dan nasabah. Ketiga, bank membeli pesanan nasabah kepada penjual atau produsen. Keempat, produsen mengirim barang pesanan nasabah yang dipesan melalui bank syariah. Kelima, nasabah menerima barang pesanannya. Keenam, setelah nasabah menerima barang pesanan nasabah membayar menggunakan sistem akad murabahah secara tangguh dengan kesepakatan keuntungan yang diterima oleh pihak bank.
Prabowo (2012:33) menjelaskan manfaat pembiayaan murabahah adalah adanya keuntungan yang muncul dari selisih harga beli dari penjual dengan harga jual kepada nasabah dan pembiayaan murabahah juga sangat sederhana, hal ini memudahkan penanganan administrasinya di bank syariah.

Pembiayaan murabahah adalah jenis pembiayaan yang sering diaplikasikan dalam bank syariah, yang pada umumnya digunakan dalam transaksi jual beli barang investasi dan barang-barang yang diperlukan oleh individu. Menurut pendapat Ismail (2011:140) barang yang boleh digunakan sebagai objek jual beli yaitu rumah, kendaraan bermotor, pembelian alat industri, pembelian pabrik, gudang dan pembelian asset lainnya yang tidak bertentangan dengan syariat Islam.

Pengawasan (controlling) adalah penemuan dan penerapan cara untuk menjamin bahwa rencana telah dilaksanakan sesuai dengan yang telah ditetapkan (Handoko, 2012:37). Pengawasan dapat didefinisikan sebagai proses untuk menjamin bahwa tujuantujuan organisasi dan manajemen tercapai.

Fungsi utama pengawasan bertujuan untuk memastikan bahwa setiap pegawai yang memiliki tanggung jawab bisa melaksanakannya dengan sebaik mungkin. Kinerja mereka dikontrol dengan sistem operasional dan prosedur yang 
Kania, et al/Jurnal Ekonomi Syariah Teori dan Terapan Vol. 3 No. 3 Maret 2016: 235-248; KESESUAIAN MEKANISME PEMBIAYAAN MURABAHAH PRODUK KPR MENURUT FATWA DSN MUI DI BANK JATIM SYARIAH SURABAYA CABANG DARMO

berlaku sehingga dapat meminimalisir kesalahan dan penyimpangan. Selanjutnya, diberikan tindakan korektif atau arahan. Fungsi pengawasan dalam Islam muncul dari pemahaman tanggung jawab individu, amanah dan keadilan. Islam memerintahkan setiap individu untuk menyampaikan amanah yang diembannya, jabatan (pekerjaan) merupakan bentuk amanah yang harus dijalankan.

Manullang (2006: 173) menjelaskan bahwa suatu sistem pengawasan haruslah mengandung prinsip-prinsip seperti adanya pemberian instruksi/wewenang kepada bawahan, dapat dengan segera melaporkan penyimpangan, fleksibel, dapat dimengerti, dapat menjamin diadakannya tindakan korektif.

Pembiayaan adalah suatu proses mulai dari analisis kelayakan pembiayaan sampai pada realisasinya. Namun realisasi pembiayaan bukanlah tahap terakhir proses pembiayaan. Setelah realisasi pembiayaan, maka pihak bank syariah perlu melakukan pemantauan dan pengawasan pembiayaan. Pengawasan produk serta kegiatan operasional pembiayaan pada bank syariah diatur dalam fatwa DSN MUI.

\section{Ketidaklancaran nasabah}

membayar angsuran pokok maupun bagi hasil pembiayaan menyebabkan adanya kolektibilitas pembiayaan. Secara umum dikategorikan menjadi lima macam yaitu:

1. Lancar atau koletibilitas 1

2. Kurang lancar atau kolektibilitas 2
3. Diragukan atau kolektibilitas 3

4. Dalam perhatian khusus atau kolektibilitas 4

5. Macet atau kolektibilitas 5

KPR syariah merupakan produk pembiayaan yang ada pada bank syariah. Kebutuhan akan tempat tinggal berkembang pesat seiring dengan permintaan masyarakat memiliki hunian yang digunakan untuk konsumtif atau investasi. Bank syariah akhirnya membuat produk KPR syariah yang mempunyai perbedaan dengan KPR pada bank konvensional. Perbedaannya terletak pada pembayaran angsuran, jika pada bank syariah pembayaran angsuran tidak berubah dari awal terjadi kesepakatan akad antara kedua belah pihak karena bank syariah menggunakan sistem bagi hasil. Sementara bank konvensional menggunakan sistem bunga, dimana bunga akan terus mengalami fluktuasi sehingga mengakibatkan angsuran bunga pembiayaan KPR tidak stabil. Transaksi yang banyak digunakan oleh perbankan syariah di Indonesia dalam menjalankan produk pembiayaan KPR adalah pembiayaan murabahah, istishna' dan ijarah, khususnya ijarah muntahiyya bi tamlik (IMBT).

Pembiayaan kepemilikan rumah (KPR) pada bank syariah dengan menggunakan akad murabahah adalah nasabah dapat membeli rumah dengan menggunakan sistem tangguh atau bisa langsung dengan sistem tunai. Namun diawal perjanjian antara kedua belah 
Kania, et al/Jurnal Ekonomi Syariah Teori dan Terapan Vol. 3 No. 3 Maret 2016: 235-248; KESESUAIAN MEKANISME PEMBIAYAAN MURABAHAH PRODUK KPR MENURUT FATWA DSN MUI DI BANK JATIM SYARIAH SURABAYA CABANG DARMO

pihak dari awal sudah melakukan kesepakatan dimana pihak bank memberitahu kepada nasabah berapa harga rumah yang diberikan oleh developer, lalu pihak bank memberitahu kepada nasabah berapa harga rumah yang diberikan dengan margin keuntungan yang diberikan kepada pihak bank sebagai penyalur antara developer dengan nasabah.

erikut ini merupakan skema KPR dengan menggunakan skim murabahah

Haris (2007: 45) menjelaskan pembiayaan KPR syariah dengan menggunakan akad murabahah adalah pertama developer perumahan menjual rumah kepada pihak bank syariah secara tunai. Pihak developer dan bank syariah melakukan kesepakatan harga yang telah ditetapkan oleh kedua belah pihak. Setelah kesepakatan harga dicapai oleh kedua belah pihak, bank syari'ah membeli kepada developer selaku supplier secara tunai. Bank syariah menjual rumah sebesar harga pokok/ asal ditambah keuntungan yang disepakati bersama, kepada nasabah KPR Syariah secara tangguh/angsuran. Setelah kesepakatan dicapai oleh kedua belah pihak, nasabah membeli rumah kepada bank syariah secara angsuran.

Nama produk KPR Syariah di Bank Jatim Syariah yaitu KPR Griya iB Barokah. KPR Griya iB Barokah yaitu pembiayaan jangka pendek, menengah atau panjang untuk membiayai pembelian rumah tinggal baik baru maupun bekas dengan sistem murabahah. Karakteristik pembiayaan KPR Griya ib Barokah menggunakan akad murabahah yaitu jangka waktu pembiayaan maksimal 15 tahun. Manfaat yang diberikan produk KPR Bank Jatim Syariah yaitu angsuran ringan dan tetap, proses cepat dan mudah, biaya administrasi ringan, online pembayaran angsuran di seluruh cabang Bank Jatim, jaringan ATM Bersama dan ATM Prima.

DSN MUI didirikan pada saat lokakarya ulama yang diselenggarakan MUI pada tanggal 28-29 Juli 1997 di Jakarta yang merekomendasikan perlunya lembaga yang menangani masalah berhubungan dengan aktivitas lembaga keuangan syariah. Pada tanggal 10 Februari 1999 diresmikan pembentukan Dewan Syariah Nasional MUI berdasarkan SK No. Kep754/MUI/II/1999. Pembentukan DSN MUI merupakan langkah efisiensi dan koordinasi para ulama dalam menanggapi isu-isu yang berhubungan dengan masalah eko.keuangan. Berbagai masalah yang memerlukan fatwa akan ditampung dan dibahas bersama agar diperoleh kesamaan pandangan dalam penanganannya oleh masing-masing Dewan Pengawas Syariah (DPS) yang ada di lembaga keuangan syariah.

Fatwa DSN-MUI yang mengatur murabahah terdapat pada fatwa no. 04/DSN-MUI/IV/2000 tentang Murabahah, fatwa no. 13/DSN-MUI/IX/2000 tentang vang muka murabahah, fatwa no. 
Kania, et al/Jurnal Ekonomi Syariah Teori dan Terapan Vol. 3 No. 3 Maret 2016: 235-248; KESESUAIAN MEKANISME PEMBIAYAAN MURABAHAH PRODUK KPR MENURUT FATWA DSN MUI DI BANK JATIM SYARIAH SURABAYA CABANG DARMO

17/DSN-MUI/IX/2000 tentang sanksi menunda pembayaran, fatwa no. 47/DSN-MUI/II/2005 tentang penyelesaian piutang murabahah, dan fatwa no. 48/DSN-MUI/II/2005 tentang penjadwalan kembali tagihan murabahah.

\section{METODE PENELITIAN}

\section{A. Pendekatan Penelitian}

Penelitian ini menggunakan pendekatan kualitatif, yakni sebuah pendekatan penelitian dengan latar untuk mengeksplorasi fenomena atau gejala sosial yang terjadi agar hasil penelitian yang diperoleh dapat dijadikan sebagai bahan pelajaran yang bermanfaat dan memberikan kontribusi terhadap pengembangan suatu konsep teori (Yin, 2009:5).

Pendekatan kualitatif ini digunakan karena dalam penelitian terkait kesesuaian fatwa DSN MUI dalam prosedur penanganan pembiayaan murabahah ditujukan untuk memahami sebuah fakta di balik fenomena guna mendapatkan gambaran secara jelas tentang kondisi sebenarnya dalam penanganan pembiayaan murabahah bermasalah.

\section{B. Ruang Lingkup Penelitian}

Rumusan masalah yang merupakan fokus studi dalam sebuah penelitian kualitatif menjadi acuan dalam menentukan ruang lingkup penelitian. Apakah pengawasan dan penanganan kolektibilitas pembiayaan murabahah di Bank Jatim Syariah Surabaya Cabang Darmo sudah sesuai dengan fatwa DSN
MUI atau tidak. Pengawasan disini meliputi persyaratan dan prosedur pembiayaan murabahah dalam produk KPR.

\section{Jenis dan Sumber Data}

Jenis data yang digunakan dalam skripsi ini adalah data primer dan data sekunder. Data primer adalah data yang diperoleh langsung dari sumbernya melalui wawancara dan observasi langsung dari lapangan yakni melakukan wawancara di Bank Jatim Syariah Cabang Darmo Surabaya. Data sekunder adalah data yang diperoleh dari sumber kedua dari data yang kita butuhkan atau peneliti dengan informan tidak terjadi hubungan secara langsung melainkan peneliti mengambil data dari peneliti lainnya (Bungin, 2005: 128). Dalam hal ini peneliti melihat referensi dari penelitian terdahulu.

Sumber data dalam penelitian ini berasal dari informan utama dan data penunjang yang memiliki kaitan dengan penelitian informan utama (key informan) dalam penelitian ini adalah pegawai Bank Jatim Syariah Surabaya bagian pembiayaan. Data penunjang dalam penelitian ini merupakan data tentang Bank Jatim Syariah yang berasal dari internet, laporan keuangan, dan sumber lain yang memiliki kaitan dengan penelitian.

\section{Teknik Pengumpulan Data}

Sugiyono (2010:73) menjelaskan ada beberapa macam wawancara yaitu wawancara terstruktur, semiterstruktur, dan tidak terstruktur : 
Kania, et al/Jurnal Ekonomi Syariah Teori dan Terapan Vol. 3 No. 3 Maret 2016: 235-248; KESESUAIAN MEKANISME PEMBIAYAAN MURABAHAH PRODUK KPR MENURUT FATWA DSN MUI DI BANK JATIM SYARIAH SURABAYA CABANG DARMO

1. Wawancara terstruktur yaitu dalam pengumpulan data telah menyiapkan instrument penelitian berupa pertanyaan-pertanyaan yang akan ditanyakan oleh informan. Dengan wawancara terstruktur ini, setiap responden diberi pertanyaan yang sama dan pengumpul data mencatatnya.

2. Wawancara semiterstruktur dimana peneliti dalam pelaksanaannya melakukan wawancara lebih bebas dibandingkan wawancara terstruktur. Tujuannya yaitu untuk menemukan permasalahan secara lebih terbuka, dimana pihak yang diajak wawancara diminta pendapat dan idenya.

3. Wawancara tidak terstruktur adalah wawancara yang bebas dimana peneliti tidak menggunakan pedoman wawancara yang telah tersusun secara sistematis dan lengkap untuk pengumpulan datanya. Pedoman yang digunakan hanya garis-garis besar permasalahan yang akan ditanyakan.

Penelitian ini menggunakan wawancara terstruktur, dimana peneliti membuat daftar pertanyaan yang sama terkait dengan penelitian yang sedang diteliti, kemudian peneliti memberi pertanyaan kepada informan yang berbeda-beda.

\section{E. Teknik Analisis Data}

Data-data yang diperoleh dari berbagai sumber diperlukan pengecekan lebih lanjut untuk memenuhi syarat objektivitas dan kredibilitas, yaitu melalui proses triangulasi teknik dimana dilakukan pengecekan data kepada sumber yang sama dangan teknik berbeda (Yin, 2009: 171). Setelah proses triangulasi teknik, data yang diperoleh dianalisis melalui tiga alur sebagai berikut (Yin, 2009: 28, 96-97).

1. Reduksi data, tahap pemilihan datadata yang telah diperoleh melalui wawancara, studi dokumen dan observasi sehingga didapatkan data yang pokok dan fokus pada obyek penelitian.

2. Display data, tahap penyajian data inti yang telah diperoleh melalui proses reduksi dikategorikan berdasarkan pokok permasalahan dan disusun ke dalam suatu pola untuk memudahkan peneliti melihat hubungan data satu dengan data lainnya.

3. Verifikasi, tahap penarikan kesimpulan berdasarkan data yang telah tersaji dan telah di cross check dengan poinpoin yang menjadi kriteria pokok pada fokus penelitian.

\section{HASIL DAN PEMBAHASAN}

\section{A. Persyaratan dan Prosedur KPR Griya iB} Barokah

Bank Jatim Syariah telah menentukan beberapa syarat yang harus dipenuhi oleh nasabah dalam mengajukan pembiayaan, persyaratan ini digunakan sebagai kehati-hatian pihak 
Kania, et al/Jurnal Ekonomi Syariah Teori dan Terapan Vol. 3 No. 3 Maret 2016: 235-248; KESESUAIAN MEKANISME PEMBIAYAAN MURABAHAH PRODUK KPR MENURUT FATWA DSN MUI DI BANK JATIM SYARIAH SURABAYA CABANG DARMO

bank dalam melakukan pembiayaan kepada nasabah. Selain itu persyaratan merupakan salah satu faktor utama untuk kelanncaran dalam menangani pembiayaan. Nasabah yang ingin mengajukan pembiayaan diberikan brosur terlebih dahulu untuk mengetahui bagaimana mekanisme serta apa saja yang harus disiapkan calon nasabah pembiayaan. Sebelum calon nasabah mendapat persetujuan pengajuan pembiayaan, nasabah harus terlebih dahulu memenuhi semua persyaratan dan prosedur yang ada. Jika semua sudah terpenuhi maka akan segera dilaksanakan akad. Persyaratan KPR Griya iB Barokah yang harus dipenuhi nasabah adalah fotocopy KTP, KK, Surat Nikah/Istri, fotocopy slip gaji, fotocopy surat keterangan bekerja atau pegawai, fotocopy NPWP, fotocopy SHM atau SHGB, dan fotocopy IMB.

Prosedur awal untuk pembiayaan KPR yaitu berkas masuk seperti persyaratan nasabah yang telah disiapkan terlebih dahulu, kemudian data yang telah masuk dilakukan verifikasi kelengkapannya jika belum ada yang lengkap maka nasabah harus melengkapi dahulu, tahap selanjutnya adalah $\mathrm{Bl}$ checking untuk mengetahui apakah nasabah mengalami pembiayaan bermasalah atau tidak, apabila tidak termasuk dalam pembiayaan bermasalah maka tahap selanjutnya yaitu observasi nasabah, kemudian usulan, persetujuan pembiayaan, setelah persetujuan pembiayaan penandatangan surat SP3. Kemudian yang terakhir yaitu realisasi akad.

Pembiayaan yang dilakukan Bank Jatim Syariah hanya diperuntukkan kepada karyawan dan wiraswasta atau dengan kata lain yang mempunyai pendapatan fix income. Untuk itu diperlukan slip gaji tiga bulan terakhir yang dapat digunakan sebagai objek analisis pendapatan nasabah tetap atau tidak. Apabila pendapatan nasabah tidak tetap maka pihak bank tidak bisa melakukan pembiayaan kepada nasabah.

\section{B. Harga KPR, Biaya dan Uang Muka}

Bank Jatim Syariah menetapkan nominal pembiayaan KPR yaitu mulai dari Rp 100.000.000 hingga Rp 5.000.000.000 dengan jangka waktu angsuran hingga 15 tahun. Pihak bank memberitahukan harga asli rumah, biaya yang harus dibayar nasabah, serta margin yang didapat oleh bank di awal perjanjian. Untuk melakukan pembiayaan awal, nasabah harus menyetorkan uang muka yang sudah ditentukan pihak bank mengikuti kebijakan BI tentang adanya LTV (Loan to Value). LTV merupakan pembatasan pembiayaan untuk rumah $<70 \mathrm{~m}^{2}$ rumah pertama sebesar $10 \%$, rumah kedua $20 \%$, rumah ketiga $30 \%$ dan seterusnya. Ada beberapa biaya yang harus dibayar oleh nasabah antara lain biaya prarealisasi, biaya asuransi, biaya materai, biaya pembukaan rekening bagi nasabah yang 
Kania, et al/Jurnal Ekonomi Syariah Teori dan Terapan Vol. 3 No. 3 Maret 2016: 235-248; KESESUAIAN MEKANISME PEMBIAYAAN MURABAHAH PRODUK KPR MENURUT FATWA DSN MUI DI BANK JATIM SYARIAH SURABAYA CABANG DARMO

belum mempunyai rekening di Bank Jatim Syariah dan biaya notaries.

Dalam praktiknya Bank Jatim Syariah telah sesuai dengan fatwa DSN MUI No. 04/DSN-MUI/IV/2000 butir enam bahwa bank harus memberitahukan secara jujur harga pokok barang dan biaya yang diperlukan kepada nasabah dan fatwa DSN MUI No. 13/DSNMUI/IX/2000 tentang vang muka dalam butir kedua karena sudah diberitahukan pada saat awal perjanjian.

\section{Jaminan}

Jaminan adalah asset pihak peminjam yang diberikan kepada pihak pemberi pinjaman, dengan tujuan untuk menjamin pembayaran kembali utang murabahah. Apabila nasabah melakukan kesengajaan tidak membayar angsuran atas pembiayaan rumah, maka jaminan tersebut menjadi hak milik bank.

Jaminan yang diberikan oleh nasabah berupa sertifikat rumah yang menjadi obyek pembiayaan. Rumah tersebut harus memiliki SHM (Sertifikat Hak Milik) atau SHGB (Sertifikat Hak Guna Bangunan) dan harus memiliki legalitas yang sah. Kriteria rumah yang menjadi obyek pembiayaan seperti jalan depan rumah harus dapat dilalui mobil, letaknya strategis, tidak dekat dengan sampah dan makam. Jaminan tersebut digunakan apabila terjadi kredit macet oleh nasabah maka pihak bank dapat menjual kembali rumah tersebut.

Fatwa DSN MUI No. 04/DSNMUI/IV/2000 butir tiga nomer satu yakni jaminan dalam murabahah dibolehkan, agar nasabah serius dengan pesanannya. Pada butir kedua dijelaskan bank dapat meminta nasabah untuk menyediakan jaminan yang dapat dipegang. Dalam prakteknya Bank Jatim Syariah sudah sesuai dengan fatwa DSN-MUI, karena pihak bank meminta jaminan pada nasabah berupa sertifikat rumah yang akan dibiayai oleh pihak bank.

\section{Denda}

Denda dalam suatu pembiayaan dikatakan wajar karena mempunyai tujuan agar nasabah dapat disiplin dengan melakukan pembayaran angsuran setiap bulannya. Nasabah yang mampu membayar, tetapi menundanunda pembayaran dengan disengaja maka pihak Bank Jatim Syariah akan memberikan sanksi berupa denda yang sudah dijelaskan di awal akad dengan tujuan agar nasabah lebih disiplin dalam melakukan kewajibannya untuk membayar angsuran setiap bulannya sampai jatuh tempo yang telah disepakati di awal perjanjian. Denda berlaku 15 hari setelah jatuh tempo. Denda yang diberikan sebesar Rp 50.000 untuk pembiayaan macet Rp 0 - Rp 1.000.000, $\operatorname{Rp} 1.000 .000-\operatorname{Rp} 2.000 .000=\operatorname{Rp} 100.000$ dan seterusnya kelipatan Rp 50.000. Dana dari denda masuk dalam dana sosial tidak bercampur dengan laporan keuangan Bank Jatim Syariah. Dalam prakteknya BJS telah sesuai dengan fatwa DSN MUI No. 17/DSN-MUI/IX/2000 butir pertama nomer satu yaitu sanksi yang dikenakan LKS 
Kania, et al/Jurnal Ekonomi Syariah Teori dan Terapan Vol. 3 No. 3 Maret 2016: 235-248; KESESUAIAN MEKANISME PEMBIAYAAN MURABAHAH PRODUK KPR MENURUT FATWA DSN MUI DI BANK JATIM SYARIAH SURABAYA CABANG DARMO

kepada nasabah yang mampu membayar tetapi menunda pembayaran dengan disengaja dan fatwa no. 17/DSNMUI/IX/2000 butir enam yaitu dana dari denda diperuntukkan sebagai dana sosial. Tetapi tidak sesuai dengan fatwa DSN MUI no. 17/DSN-MUI/IX/2000 bahwa sanksi dapat berupa denda sejumlah vang yang besarnya ditentukan berdasar kesepakatan. Dalam prakteknya penetapan denda di Bank Jatim Syariah berdasarkan besarnya angsuran.

\section{E. Penanganan Kolektibilitas Pembiayaan}

Kolektibilitas pembiayaan dikatakan bermasalah jika berada pada tahap kolektibilitas 2 atau tahap kurang lancar sampai tahap macet atau kolektibilitas 5. Pada tahap tersebut pihak bank harus mulai melakukan pengawasan dan melakukan kunjungan langsung pada nasabah yang bersangkutan. Bagi nasabah yang mengalami penurunan kolektibilitas pembiayaan atau pembayaran angsuran tidak tepat waktu, maka pihak Bank Jatim Syariah akan memberikan kelonggaran waktu sesuai kesepakatan dengan nasabah yang bersangkutan hingga dapat melakukan pembayaran angsuran kembali (restrukturisasi). Langkah awal yang dilakukan oleh pihak bank apabila mengetahui ada nasabah yang mengalami penurunan kolektibilitas pembiayaan yakni dengan memberitahukan via telepon bahwa angsuran sudah jatuh tempo, jika tidak mendapat jawaban akan dilakukan kunjungan pada nasabah tersebut.

Dalam prakteknya, Bank Jatim Syariah telah sesuai dengan fatwa DSN MUI No. 48/DSN-MUI/II/2005 butir tiga yakni dalam melakukan penjadwalan kembali (rescheduling) tagihan murabahah perpanjangan masa pembayaran harus berdasarkan kesepakatan kedua belah pihak.

\section{F. Penanganan Kolektibilitas Pembiayaan} Macet

Apabila nasabah berada dalam kolektibilitas pembiayaan macet, semua surat peringatan 1 hingga 3 sudah harus dikeluarkan kepada nasabah. Jika tidak ada tanggapan atau itikad baik dari nasabah untuk melunasi angsurannya sesuai dengan jumlah dan waktu yang disepakati, maka pihak bank akan melakukan upaya jual agunan nasabah dengan sistem lelang. Obyek yang dijadikan lelang adalah rumah yang dibiayai sebagai jaminan tersebut. Dari hasil penjualan tersebut apabila ada kelebihan maka pihak bank akan mengembalikan pada nasabah.

Fatwa DSN MUI No. 47/DSNMUI/II/2005 butir satu yakni obyek murabahah atau jaminan lainnya dijual oleh nasabah kepada atau melalui LKS dengan harga pasar yang disepakati, butir kedua dijelaskan nasabah melunasi sisa utangnya kepada LKS dari hasil penjualan, butir tiga dijelaskan apabila hasil penjualan melebihi sisa utang maka LKS wajib mengembalikan sisanya kepada 
Kania, et al/Jurnal Ekonomi Syariah Teori dan Terapan Vol. 3 No. 3 Maret 2016: 235-248; KESESUAIAN MEKANISME PEMBIAYAAN MURABAHAH PRODUK KPR MENURUT FATWA DSN MUI DI BANK JATIM SYARIAH SURABAYA CABANG DARMO

nasabah. Dalam praktiknya, Bank Jatim Syariah telah sesuai dengan fatwa diatas.

\section{Simpulan}

Kesimpulan dari hasil penelitian tentang Kesesuaian Pengawasan dan Penanganan Kolektibilitas Pembiayaan Murabahah Produk KPR Menurut Fatwa DSN MUI di Bank Jatim Syariah dilihat dari enam indikator yaitu, harga, denda, jaminan, penanganan pembiayaan murabahah bermasalah dan pembiayaan macet yang disesuaikan dengan fatwa DSN MUI No. 04/DSNMUI/IV/2000 tentang murabahah, No. 13/DSN-MUI/IX/2000 tentang vang muka murabahah, No. 17/DSN-MUI/IX/2000 tentang sanksi atas nasabah mampu yang menunda-nunda pembayaran, No. 47/DSN-MUI/II/2005 tentang penyelesaian piutang murabahah bagi nasabah tak mampu bayar, No.48/DSN-MUI/II/2005 tentang penjadwalan kembali tagihan murabahah, dalam praktiknya Bank Jatim Syariah telah sesuai dengan fatwa DSN MUI. Namun, ada satu poin yakni pada penetapan denda yang tidak sesuai dengan fatwa DSN MUI terkait besarnya jumlah denda yang berbeda tergantung dari besarnya angsuran.

\section{DAFTAR PUSTAKA}

Antonio, Muhammad Syafi'i. 2001. Bank Syariah: dari Teori ke Praktek. Jakarta: Gema Insani.
Arifin, Zainul. 2009. Dasar-Dasar Manajemen Bank Syariah. Jakarta: Kelompok Pustaka Alvabet.

Ascarya. 2011. Akad dan Produk Bank Syariah. Jakarta: PT Rajawali Pers.

Bungin, Burhan. 2005. Penelitian Kualitatif: Komunikasi, Ekonomi, Kebijakan Publik, dan Ilmu Sosial Lainnya. Jakarta: Balai Pustaka.

Fajruka, Ardhi. 2011. Perbandingan Ketentuan Musyarakah Mutanaqishah dan Murabahah untuk Pembiayaan Perumahan Syariah pada Bank Syariah di Indonesia. Skripsi diterbitkan UI (www.lib.ui.ac.id)diakses pada 5 Agustus 2015.

Handoko, Hani. 2012. Manajemen. Jakarta: Balai Pustaka.

Haris, Helmi. 2007. Pembiayaan Kepemilikan Rumah (Sebuah Inovasi Pembiayaan Perbankan Syariah). Jurnal Ekonomi Islam La Riba vol.1 no.1 (online) (http://journal.uii.ac.id) diakses pada 7 Agustus 2015.

Ismail. 2011. Perbankan Syariah. Jakarta: PT Fajar Interpratama Offset.

Karim, Adiwarman. 2007. Bank Islam Analisis Figh dan Keuangan. Jakarta: PT Rajawali Pers.

Kartika, Nia. 2015. Kesesuaian Produk KPR Syariah dengan Akad Murabahah pada Fatwa DSN MUI. Skripsi diterbitkan UNAIR (www.adln.lib.unair.ac.id) diakses pada Agustus 2015. 
Kania, et al/Jurnal Ekonomi Syariah Teori dan Terapan Vol. 3 No. 3 Maret 2016: 235-248; KESESUAIAN MEKANISME PEMBIAYAAN MURABAHAH PRODUK KPR MENURUT FATWA DSN MUI DI BANK JATIM SYARIAH SURABAYA CABANG DARMO

Manullang. $2006 . \quad$ Dasar-Dasar Manajemen. Yogyakarta: Gadjah Mada University Press.

Muhammad. 2000. Sistem dan Prosedur Operasional Bank Syariah. Yogyakarta: UII Press.

- 2004. Manajemen Dana Bank Syariah. Yogyakarta: Ekonisia.

-.--2005. Bank Syariah : Analisis

Kekuatan, Peluang, Kelemahan dan Ancaman. Yogyakarta: Ekonisia.

Muhammad. 2011. Audit dan Pengawasan pada Bank Syariah. Yogyakarta: UII Press.

Prabowo, Bagya. 2012. Perbankan Syariah. Yogyakarta: UII Press.

Qur'an in Word ver 1.3 created by Muh. Taufiq.

Sudarsono, Heri. 2008. Bank Dan Lembaga Kevangan Syariah. Yogya: Ekonisia.

Sugiyono, 2010, Metodologi Penelitian Kuantitatif, Kualitatif, dan R\&D, Bandung. Alfabeta.

Rivai, Veithzal. 2008. Islamic Financial Management. Jakarta: PT Raja Grafindo Persada.

Wiroso. 2009. Produk Perbankan Syariah. Jakarta: LPFE Usakti.

Yin, Robert. 2009. Studi Kasus Desain dan Metode. Jakarta: PT Raja Grafindo Persada.

http://www.dsnmui.or.id/index.php?page =fatwa fatwa tentang murabahah. Diakses pada tanggal 3 Agustus 2015 pukul 19.00 WIB. 